\title{
Consumer Ethnocentrism and Country of Origin: Effects on Online Consumer Purchase Behavior in Times of a Pandemic
}

\author{
Luis José Camacho ${ }^{1, * \mathbb{D}}$, Patricio Esteban Ramírez-Correa ${ }^{2, * \mathbb{D}}$ and Cristian Salazar-Concha ${ }^{3, *(D)}$ \\ 1 School of Business, SUNY Empire State College, College Road, Selden, NY 11784, USA \\ 2 School of Engineering, Universidad Católica del Norte, Larrondo 1281, Coquimbo 1780000, Chile \\ 3 Faculty of Economic and Administrative Sciences, Administration Institute, Universidad Austral de Chile, \\ Independencia 631, Valdivia 5110566, Chile \\ * Correspondence: luis.camacho@esc.edu (L.J.C.); patricio.ramirez@ucn.cl (P.E.R.-C.); \\ cristiansalazar@uach.cl (C.S.-C.); Tel.: +1-212-647-7800 (ext. 1773) (L.J.C.)
}

Citation: Camacho, L.J.;

Ramírez-Correa, P.E.; Salazar-Concha,

C. Consumer Ethnocentrism and

Country of Origin: Effects on Online Consumer Purchase Behavior in Times of a Pandemic. Sustainability 2022, 14, 348. https://doi.org/ $10.3390 /$ su14010348

Academic Editors: María del Carmen Valls Martínez, José-María Montero and Pedro Antonio Martín Cervantes

Received: 15 November 2021 Accepted: 26 December 2021 Published: 29 December 2021

Publisher's Note: MDPI stays neutral with regard to jurisdictional claims in published maps and institutional affiliations.

Copyright: (c) 2021 by the authors Licensee MDPI, Basel, Switzerland. This article is an open access article distributed under the terms and conditions of the Creative Commons Attribution (CC BY) license (https:// creativecommons.org/licenses/by/ $4.0 /)$.

\begin{abstract}
Electronic commerce has shown exponential growth over the past decade, but the impact of COVID-19 has exceeded all expectations. Based on the theory of planned behavior, this paper aims to investigate the relationship between consumer ethnocentrism and internet purchase behavior in times of pandemics. Data was collected from 294 online purchasers, and the analysis was conducted utilizing a Partial Least Squares Structural Equation Modeling approach. The results indicate no significant impact on the relationship between the planned online purchase behavior and the country of origin when consumers face a health crisis. Additionally, the outcomes show that attitude toward online shopping positively affects online purchase behavior.
\end{abstract}

Keywords: ethnocentrism; country of origin; internet purchasing behavior; PLS-SEM; COVID-19

\section{Introduction}

For decades, marketing scholars and practitioners have investigated the influence of globalization on consumer behavior across countries, particularly in connection with issues of worldwide marketing standardization-adaptation [1,2]. According to [3], market convergence has encouraged sociologists, psychologists, and marketers to examine the interaction of global and local influences on consumer behavior in the context of globalization. As Ref. [4] defined, global consumer acculturation is the effect of culture on consumer behavior. Therefore, it is vital to research the impact of individual cultural features on consumers' behavior, even if the study concentrates on single cultural characteristics and does not include studies of how the complex total influences purchasing and consumer behavior (p. 785).

Due to advancements in communication technology, information has spread far and wide, giving businesses and goods a global audience. As the Internet has been more widely accepted and used, customers from across the globe have access to more goods and services through safe online purchasing [5]. New transportation technologies have offered customers more accessible access to other countries, where they may immediately interact with foreign goods and advertising. These exposures have impacted customer expectations and product selections across many attributes [6]. E-commerce has grown in popularity because of improved Internet technology. Consumers now have quick access to the product information on the Internet and may use shopping channels to make online purchases [7].

The development of the Internet has established a tight relationship with producers and consumers, locally and internationally. All these participants have become important and conscious contributors to sustainable consumption [8]. Although there is no agreement about the sustainable consumption definition, one of the most accepted, presented in 1994, defines it as "the use of goods and services that respond to basic needs and bring a better quality of life, while minimizing the use of natural resources, toxic materials and 
emissions of waste and pollutants over the life cycle, so as not to jeopardize the needs of future generations" [9]. In that sense, the expansion of e-commerce has influenced those changes and emerged along with sustainable development. Therefore, its significance has been considered to have an extraordinary impact on the modern world [10]. Sustainable development establishes the paradigm of economic growth by integrating it with environmental protection criteria [11], considering current and future generations' needs, and acknowledging the connection of its three dimensions: Environmental, Social, and Economic [12].

Evidence suggests that consumers in emerging nations are less ethnocentric [13]. They highly prefer imported goods from developed countries [14]. One significant factor contributing to this occurrence is prestige. Consumers often utilize the Country of Origin (COO) as a quick indicator when deciding whether or not to buy goods and brands made in the target nation [15]. Hence, many studies on the COO's impact on customer behavior have developed in international marketing and business literature [16].

Corporations working based on online retail and e-commerce implement strategies to attract consumers to their brands and product lines, facilitating online shopping and bidirectional communication with their customers. Undoubtedly, corporations should consider, in all senses, the importance of e-commerce sustainability and sustainable regulations when creating offers, processes, and marketing strategies [17].

Previous statements are important due to the fact that e-commerce may assist in achieving a sustainable competitive advantage, which contributes to the long-term stability of the ecological system. According to [18], there is a link between perceived sustainability and customer engagement in e-commerce, and by reducing the number of visits to the store, e-commerce shopping may help to encourage environmentally-friendly lifestyles [19].

Consumer ethnocentrism (CE) has become progressively essential to researchers in consumer behavior and international marketing because it directly influences consumers' attitudes and buying preferences. An example of ethnocentrism is when a person desires to explore their identity and belong to a group/community [20]. Purchasing foreign goods is considered harmful because it is detrimental to the home economy, unpatriotic, and has a damaging influence on domestic jobs [21]. CE has a moral basis that extends beyond economic and functional concerns. Some customers think buying foreign goods is disloyal and immoral since it harms the native economy and destroys employment. Highly ethnocentric customers often make erroneous judgments and overvalue local items relative to imported goods [22] Thus, understanding customer behavior in various settings is critical for international marketing. As markets grow borderless and completely interconnected, it is crucial to determine if customers are concerned about the COO of goods and to what degree countries and cultures favor local goods over international ones.

Even though many researchers have investigated $C E$ in various countries and have concentrated on $\mathrm{CE}$ results, little is known regarding the proportional relevance of its effects on the COO and Theory of Planned Behavior (TPB). What is more, there is a lack of explicitly evaluating consumer behavior through internet purchases during a pandemic in this framework. Nevertheless, there is mounting evidence that $\mathrm{COO}$ and $\mathrm{CE}$ are significant determinants of product assessments and purchasing choices [23,24]. Consequently, this research emphasized the roles of $\mathrm{COO}$ and $\mathrm{CE}$ in understanding consumer purchasing behavior. Thus, the current study attempts to expand the TPB model by incorporating key online purchasing variables, such as $\mathrm{COO}$ and $\mathrm{CE}$, and improving our capacity to forecast intention and explain online consumers' choices. As a result, this research develops and examines a theoretical framework based on the TPB model to examine the connection between variables and explain online consumer behavior during pandemics.

The present study adds to the body of knowledge in a variety of ways. First, it may fill a knowledge gap in $\mathrm{COO}$ and $\mathrm{CE}$ research by examining online consumer responses during pandemics. Second, we create an experimentally tested model that explains the links between $\mathrm{COO}$ and $\mathrm{CE}$ and predicts online local and international brand purchase decisions using the TPB. Finally, we conduct an experimental evaluation of the model 
using data from a representative sample of a developing country to see if the indicated relationships hold.

Partial least squares structural equation modeling (PLS-SEM) is now well-established as a method for analyzing complex causal relationships among latent variables [25]. Moreover, this analysis method has been used extensively in many contexts, particularly in international marketing [26]. In this study, this approach is used to validate the theoretical framework.

The remaining document is organized as follows. The subsequent section sets out the conceptual framework and hypothesis. Afterward, measurements and procedures are discussed. Next, the empirical results are examined. Finally, we discuss the implications for theory and practice, highlight limitations, and provide suggestions for further study.

\section{Conceptual Framework and Research Model}

\subsection{Consumer Ethnocentrism}

Ethnocentrism, or more broadly, in-group prejudice, is a prevalent empirical phenomenon in human cultures. For example, Ref. [27] refers to CE as the beliefs held by consumers about the appropriateness, indeed morality, of purchasing foreign-made products. Highly ethnocentric consumers refuse to buy imported products and may even chastise others for doing so [28]. The impact of ethnocentrism extends not only to businesses or governments but also to the consumer level, on which most of the academic study has concentrated.

CE refers to preferences for home over international goods in marketing research [27]. The idea is helpful in forecasting customer receptivity to foreign brands [3]. For consumers and strategic decision-makers in the global economy, assessing CE levels is critical since doing so may indicate where standardization is feasible and specialized services are required [29] (p. 58). Aspects such as global positioning [30], market entry mode decisions [31], and the materialization of COO effects [32] are also influenced by CE [33]. CE's impact has often been theorized in terms of social identity theory, in which customers are seen as actors motivated to adhere to and align themselves with the standards and values of their in-groups in the hopes that doing so will provide them with a good social image [34].

Despite its many theoretical and practical uses and repeated requests for conceptual revision, the CE construct has remained unchanged since 1987. According to [35], it has been suggested by many scholars that $\mathrm{CE}$ must be conceptually reexamined, along with its quantification. The rise in calls is due to empirical data contradicting the original conception of $\mathrm{CE}$ as a unidimensional phenomenon [36]. The Consumer Ethnocentrism Tendencies Scale (CETSCALE) is utilized to operationalize the concept, which raises questions regarding the measurement's relevance and generalizability [27]. On the other hand, Ref. [37] indicated that many researchers linked the CETSCALE to social desirability bias, response style bias, and the dimensionality issues raised in previous research.

Shimp and Sharma [27] coined CE as American consumers' views about the propriety, even morality, of purchasing foreign-made goods. According to these authors, from the ethnocentric consumer's viewpoint, buying imported goods is terrible since it harms the home economy, results in job losses, and is unpatriotic. CE was quantified using the CETSCALE, created by these researchers. All the scale's items indicate a preference for USmade goods over foreign-made goods and a rejection of purchasing or importing foreign goods. As a result, it has been utilized successfully throughout the globe (e.g., [38], with acceptable reliability and validity.

Ethnocentrism is a broad concept that encompasses all aspects of ethnicity. Ethnicity is a prehistoric human social identity. For example, Ref. [39] specifies that it is still one of people's most significant social identities, since it fulfills fundamental psychological requirements and has an evolutionary foundation because it is concerned with family groupings and genetic similarities. According to [27], CE derives from Summer's [39] broad notion of ethnocentrism. In other words, CE seems to be a narrow application and adaption of ethnocentrism to the purchase of imported consumer goods. Therefore, $\mathrm{CE}$ originated from the broader notion of ethnocentrism [37] (p. 382). However, the two 
concepts are different, and CE is best understood considering generic ethnocentrism. On the other hand, Ref. [40] suggested that CE may mean many other things, such as beliefs, dispositions, or characteristics. Hence, it is best understood as an attitude and socialpsychological construct. CE may fulfill the requirements of ethnocentrism by strengthening ethnic group strength by purchasing goods from the nation where their ethnic group resides. However, it is probable that CE may not flow directly from ethnocentrism, but that multiple categories mediate the connections.

On the other hand, non-ethnocentric customers compare the quality and performance of international and local goods and select the best one [27]. According to [41]'s research on ethnocentric sentiments in consumer behavior, there is a general dislike of imported goods, making it difficult for them to succeed in foreign marketplaces. In today's more globalized society, cosmopolitan attitudes are believed to decrease ethnocentric sentiments. However, Ref. [27] found that CE promotes patriotism and stresses cultural and ethnic identity, affecting the global economic environment, particularly in times of crisis. Consistent with the study of [42], the desire to help local businesses typically rises during economic crises in many nations.

Subsequent ethnocentrism research has concentrated on the willingness to pay for foreign goods and the intention to buy and attitudes about foreign products [43]. In the same vein, Ref. [44] said that CE is associated with a negative attitude toward foreign goods, and, at the same time, the desire to buy domestically is positively impacted. In the opinion of [45], the explanation for this conclusion is that consumers' cultural values significantly influence consumer behavior. On the other hand, Ref. [46] stated that customers choose imports from nations with similar cultural backgrounds to their own. Thus, CE significantly impacts purchasing habits for domestic and foreign products, with particular attention to market segmentation, communications processes, and methods, defining the correct target markets, and creating a unique selling proposition that can be decoded by consumers nationally. Therefore, we hypothesized:

Hypothesis 1 (H1). High consumer ethnocentrism will produce lower online consumer purchase behavior.

Hypothesis 2 (H2). Consumer ethnocentrism positively influences country of origin.

\subsection{Country of Origin}

The COO effect is generated from customer views of a country's identity, which means that goods and companies benefit from and face criticism based on preconceived notions. Examples are high or low quality, newly attractive or old fashion and lousy design, simply by being recognized worldwide as typical for that country [24,47,48]. As per [49], it has been recognized that this is due to that nation's culture, tradition, and history. In other words, the COO theory is rooted in history. According to several sources, the COO may be described as either where a product is produced, manufactured [50] or where the company's headquarters are situated [51]. A study conducted by [52] defines the COO as an intangible barrier, based on consumer prejudice, which benefits well-known companies and harms newcomers to the market. Nevertheless, many academics are interested in COO, as shown by the wide range of definitions [5]. According to [32] evidence supports the presence of the $\mathrm{COO}$ effect even when the perceived brand origin is incorrect, calling into question the idea that the impact of $\mathrm{COO}$ on customer attitudes and behaviors is exaggerated (e.g., [53]. In addition, a meta-analysis conducted by [54] found that customer perception of quality and purchase intent are influenced by $\mathrm{COO}$, which aids their decision-making process.

Based on their research, Ref. [55] highlight COO and its impact on customer assessments of items as being one of the most extensively researched topics in marketing, with hundreds of journal papers dedicated to it. Additionally, Ref. [54] demonstrated that the $\mathrm{COO}$ effect is more than a cognitive signal. It also has symbolic and emotional implications. Indeed, the origin of goods transmits a set of associations and symbols associated with the nation of origin [56]. Therefore, the COO effect demonstrates how customers have varying opinions about goods from different nations, indicating that they utilize provenance as 
a criterion for product quality, either alone or with other criteria [57]. When consumers interconnect the perceived quality with $\mathrm{COO}$, they are more likely to pay attention to how much they value a product and how confident they are in their purchase, which reduces the chance of making a mistake or cognitive dissonance [58].

Many research studies show that COO significantly impacts purchase decisions $[59,60]$, although others have shown that the origin does not affect consumer preferences or is a minor factor [61]. Nonetheless, it is necessary to emphasize that these findings are linked to the relative significance given to those characteristics compared to the attribute origin. According to [62], customers are interested in direct quality indicators, and in [63]'s findings, consumers are focused on pricing. In a similar way, Ref. [64] stated that when local products are perceived as low quality, there is evidence of rejecting them and preferring imports. In other words, the COO impact is observed in a limited number of goods and at varying degrees of strength, making it difficult to generalize for any product or nation [65]. According to [66], customers' ethnocentric emotions are exacerbated by the $\mathrm{COO}$ effect. Consumers' perceptions of imported foods are influenced by the economic growth of the nation of origin, with goods from developed countries often receiving better ratings than those from developing ones [67].

The COO effect has been linked to various marketing variables that influence customer behavior, including familiarity [68], and consumers form opinions about countries based on their acquaintance with foreign goods. Understanding may have a significant role in comprehending the proclivity for using $\mathrm{COO}$ data and its impact on other factors [69]. For example, consumers may decide not to purchase a foreign product that they have never heard of since they are concerned about its quality [70]. According to [49], customers acquainted with a particular product class are less likely to use $\mathrm{COO}$ as a signal in product assessment. Furthermore, these authors discovered that familiarity with a specific product from a foreign country influences assessments but does not always result in more positive views.

Hypothesis 3 (H3). A higher-country-of-origin effect will produce higher online consumer purchase behavior.

\subsection{Theory of Planned Behavior}

According to the TPB, a person's desire to engage in a particular activity determines whether that individual gets involved in that conduct. To some extent, the intent is shaped by attitudes toward the action, subjective standards about participating in it, and assessments of whether the person would be successful. Ajzen [71] defined the last three constructs as follows. Attitude is the degree to which a person has a positive or negative evaluation of the conduct at issue. In general, the more positive an individual's attitude toward the action, the greater their intention to do it. Subjective norms perceive societal pressure on a person to perform or not perform a behavior. It is believed that perceived behavioral control reflects both prior experience and expected obstacles and repercussions [72]. Finally, Ajzen connects perceived behavioral control with Bandura's concept of perceived self-efficacy [73]. Thus, the TPB establishes a relationship between perceived behavioral control and behavioral achievement

According to [71], in the TPB, individual behavior is determined by behavior intentions. Intention plays a critical role in mediating behavior and other variables, such as attitude, subjective norm, and perceived behavioral control. Attitude is the degree to which a person has a positive or negative evaluation of the conduct at issue. In general, the more positive an individual's attitude toward the action, the greater their intention to do it. Subjective norms perceive societal pressure on a person to perform or not perform a behavior. It is believed that perceived behavioral control reflects both prior experience and expected obstacles and repercussions. In addition, and based on the findings of [74], people's conduct is heavily influenced by their belief in their abilities. When activities are regarded as difficult, or performance obstacles exist, perceived behavioral control becomes essential. Furthermore, 
Ref. [75] found that brand awareness is the first stage in creating good connections and positive attitudes between consumers and products.

The TPB has been used in online purchases and information technology studies [76,77]. According to [78], consumers' desire to use information technology goods is influenced by attitude, subjective norms, and perceived behavioral control. Other researchers have found that TPB effects, subjective norms, and perceived behavioral control were direct antecedents of the desire to embrace mobile commerce [79]. In an empirical study conducted by [77], which focused on internet purchasing, attitude and perceived behavioral control were predictors of internet purchasing; consumer's internet purchasing behavior did not significantly influence subjective norm. In addition, the study demonstrated that the normative structure impacts subjective norms, and internet trustworthiness influenced attitudes regarding online buying. A positive effect of self-efficacy on perceived behavioral control was verified. Therefore, we hypothesized:

Hypothesis 4 (H4). Perceived behavioral control will positively influence online consumer purchase behavior.

Hypothesis 5 (H5). Attitude toward online purchases will positively influence online consumer purchase behavior.

Hypothesis 6 (H6). Subjective norms will positively influence online consumer purchase behavior.

\subsection{Research Model}

Figure 1 shows the research model of the study. In the model, Attitude Toward Online Purchase (ATOP), Subjective Norms (SN), Perceived Behavioral Control (PBC), Consumer Ethnocentrism (CE), and Country of Origin (COO) determine online consumer purchase behavior (OPB). Additionally, CE determines COO.

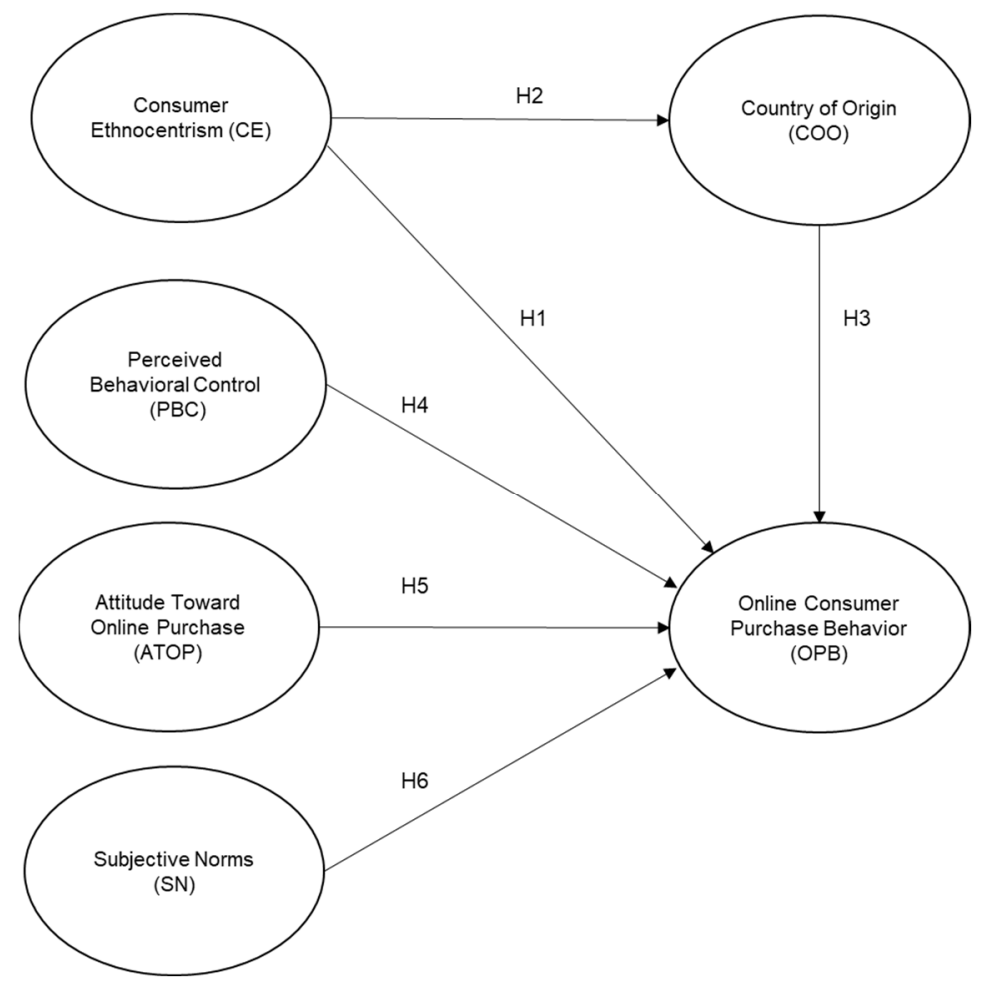

Figure 1. Research model.

\section{Materials and Methods}

Colombian consumers aged 18 and above from three major cities, Bogotá, Medellín, and Bucaramanga, participated in this research. The survey was distributed through email blasting and using Survey Monkey services. The email outlined the study's goals and 
invited recipients to participate in an online poll in which they would remain anonymous. Every other week, we sent out email notifications to all the prospective participants. The data-collecting period lasted 20 weeks. The researchers received 398 questionnaires. However, 104 had to be discarded since they lacked crucial data for this investigation. Two hundred and ninety-four questionnaires were approved, yielding a response rate of 73.9 percent.

Regarding age, 23.1 percent of the participants identified as 18-24 years old, while 17.6 percent identified as $45-54$ years old. In terms of gender, 51.7 percent of the participants were female, and 48.3 percent were male. Regarding educational attainment, 30.2 percent reported some college studies, 25.9 percent a bachelor's degrees, 9.2 percent some graduate studies but no degree, and 29.9 percent a graduate degree, respectively (see Table 1).

Table 1. Demographic Characteristics.

\begin{tabular}{ccc}
\hline Demographic Variable & Frequency & Percent \\
\hline Gender & 164 & \\
Female & 153 & 51.7 \\
Male & & 48.3 \\
Age & 92 & 31.3 \\
$18-24$ & 49 & 16.7 \\
$25-34$ & 54 & 18.4 \\
$35-44$ & 70 & 23.8 \\
$45-54$ & 26 & 8.8 \\
$55-64$ & 3 & 1.0 \\
$65+$ & & \\
Education & 14 & 4.8 \\
High School Degree or & 89 & 30.2 \\
equivalent & 76 & 25.9 \\
Some college but no degree & 27 & 9.2 \\
Bachelor's Degree & 88 & 29.9 \\
Some Graduate Study but no & & \\
degree & & \\
Graduate & &
\end{tabular}

The questionnaire was created using scales that had been established in earlier research. The questionnaire included questions that were scored on a seven-point Likert scale. CETSCALE was proposed by [27], and it was used to develop the CE scale. The $\mathrm{COO}$ was determined using the scale of [51]. The TPB was determined using the model for the Internet buying environment proposed by [77]. Four latent variables were included, adapted from the TPB. Four items evaluated attitudes toward online purchases. In addition, two items assessed subjective norms, and two items evaluated perceived behavioral control. To verify semantic equivalence in the translation of the scales from English to Spanish, a pilot study with 50 participants was performed. A single question assessed online consumer purchase behavior: How much would you say you spend on Internet purchases each month? The questionnaire is exhibited in Table A1.

\section{Analysis and Results}

Partial Least Squares Structural Equation Modeling (PLS-SEM) was employed to analyze the data. The selection of the technique is due to the exploratory nature of the hypothesized relationships in this study. The PLS analysis consists of two phases, examining the validity of the measurement model and evaluating the structural model. The results of each stage will then be reported.

\subsection{Measurement Model}

The guidelines for the evaluation of the model were applied in accordance with the procedures described in the literature. Table 2 shows the measurement models, outer loadings exceeding 0.707 met technical recommendations, with the only exception being 
SN1 with a value of 0.676 . Furthermore, composite reliability and average variance extracted (AVE) exceeded 0.83 and 0.59 , respectively. Therefore, the convergent validity has been proven.

Table 2. Cronbach's Alpha, Composite Reliability, AVE, and Factor Loadings.

\begin{tabular}{|c|c|}
\hline Latent Variables & Value \\
\hline \multicolumn{2}{|c|}{ Attitude Toward Online Purchase (ATOP) } \\
\hline Cronbach's Alpha & 0.907 \\
\hline Composite Reliability & 0.935 \\
\hline AVE & 0.782 \\
\hline ATOP1 & 0.907 \\
\hline ATOP2 & 0.856 \\
\hline ATOP3 & 0.898 \\
\hline ATOP4 & 0.877 \\
\hline \multicolumn{2}{|c|}{ Subjective Norms (SN) } \\
\hline Cronbach's Alpha & 0.754 \\
\hline Composite Reliability & 0.835 \\
\hline AVE & 0.724 \\
\hline SN1 & 0.676 \\
\hline SN2 & 0.996 \\
\hline \multicolumn{2}{|c|}{ Perceived Behavioral Control (PBC) } \\
\hline Cronbach's Alpha & 0.723 \\
\hline Composite Reliability & 0.870 \\
\hline AVE & 0.771 \\
\hline PBC1 & 0.806 \\
\hline PBC2 & 0.944 \\
\hline \multicolumn{2}{|c|}{ Consumer Ethnocentrism (CE) } \\
\hline Cronbach's Alpha & 0.933 \\
\hline Composite Reliability & 0.942 \\
\hline AVE & 0.599 \\
\hline CE1 & 0.743 \\
\hline CE2 & 0.754 \\
\hline CE3 & 0.744 \\
\hline CE4 & 0.730 \\
\hline CE5 & 0.807 \\
\hline CE6 & 0.851 \\
\hline CE7 & 0.738 \\
\hline CE8 & 0.829 \\
\hline CE9 & 0.754 \\
\hline CE10 & 0.725 \\
\hline CE11 & 0.825 \\
\hline \multicolumn{2}{|c|}{ Country of Origin (COO) } \\
\hline Cronbach's Alpha & 0.862 \\
\hline Composite Reliability & 0.900 \\
\hline AVE & 0.644 \\
\hline COO1 & 0.785 \\
\hline $\mathrm{COO} 2$ & 0.838 \\
\hline $\mathrm{COO} 3$ & 0.747 \\
\hline $\mathrm{COO} 4$ & 0.831 \\
\hline COO5 & 0.808 \\
\hline
\end{tabular}

Discriminant validity was assessed based on the Fornell-Larcker criterion and the Heterotrait-Monotrait Ratio (HTMT) approach. Table 3 indicates these results, the square roots of the AVEs for the latent variables being higher than the correlations between them. Furthermore, HTMT values were all below 0.50 , offering full support for discriminant validity. 
Table 3. Discriminant validity analysis.

\begin{tabular}{|c|c|c|c|c|c|c|}
\hline Latent Variable & ATOP & PBC & $\mathrm{CE}$ & $\mathrm{COO}$ & SN & OPB \\
\hline \multicolumn{7}{|c|}{ Fornell-Larcker criterion } \\
\hline ATOP & 0.884 & & & & & \\
\hline PBC & 0.365 & 0.878 & & & & \\
\hline $\mathrm{CE}$ & -0.080 & -0.178 & 0.774 & & & \\
\hline $\mathrm{COO}$ & -0.047 & -0.020 & 0.423 & 0.802 & & \\
\hline $\mathrm{SN}$ & 0.268 & 0.143 & -0.023 & -0.005 & 0.851 & \\
\hline OPB & 0.378 & 0.263 & -0.116 & 0.047 & 0.159 & \\
\hline \multicolumn{7}{|c|}{ Heterotrait-Monotrait Ratio (HTMT) } \\
\hline PBC & 0.452 & & & & & \\
\hline $\mathrm{CE}$ & 0.092 & 0.217 & & & & \\
\hline $\mathrm{COO}$ & 0.057 & 0.062 & 0.456 & & & \\
\hline $\mathrm{SN}$ & 0.287 & 0.224 & 0.082 & 0.070 & & \\
\hline OPB & 0.393 & 0.289 & 0.133 & 0.063 & 0.122 & \\
\hline
\end{tabular}

\subsection{Structural Model}

Table 4 and Figure 2 present the analysis of the structural model. The assessment of the structural models started with the evaluation of the Standardized Root Mean Square Residual (SRMR) for the estimated models. As a result, the model has an SRMR of 0.058, an appropriate fit based on the cut-off value of 0.08 . Overall, both OPB $\mathrm{R}^{2}$ and COO R indicate lower effects. Similarly, the $\mathrm{Q}^{2}$ predict values show the lower predictive accuracy for the model.

Table 4. Path coefficients and indexes of structural models.

\begin{tabular}{cc}
\hline Relationships/Indexes & Global \\
\hline $\mathrm{H} 1: \mathrm{CE} \rightarrow \mathrm{OPB}$ & $-0.116 \mathrm{~ns}$ \\
$\mathrm{H} 2: \mathrm{CE} \rightarrow \mathrm{COO}$ & $0.423^{* * *}$ \\
$\mathrm{H} 3: \mathrm{COO} \rightarrow \mathrm{OPB}$ & $0.114 \mathrm{~ns}$ \\
$\mathrm{H} 4: \mathrm{PBC} \rightarrow \mathrm{OPB}$ & $0.122^{*}$ \\
$\mathrm{H} 5:$ ATOP $\rightarrow \mathrm{OPB}$ & $0.314^{* * *}$ \\
$\mathrm{H} 6: \mathrm{SN} \rightarrow \mathrm{OPB}$ & $0.055 \mathrm{~ns}$ \\
$\mathrm{R}^{2}$ of OPB & 0.178 \\
$\mathrm{R}^{2}$ Adjusted of OPB & 0.164 \\
$\mathrm{Q}^{2}$ Predict of OPB & 0.142 \\
$\mathrm{R}^{2}$ of COO & 0.179 \\
$\mathrm{R}^{2}$ Adjusted of COO & 0.176 \\
$\mathrm{Q}^{2}$ Predict of COO & 0.168 \\
SRMR & 0.058 \\
\hline
\end{tabular}

Notes: ${ }^{* * *} p$-value $<0.001,{ }^{*} p$-value $<0.05$, ns non-significant.

Next, we examined the hypothesized relationships. For the research model, beta coefficients are positive and significant for the relationships between CE and COO, PBC and OPB, and ATOP and OPB but not for the other relations. The analysis supports the beta coefficients being significantly different from zero between the independent variables PBC, ATOP, and the variable OPB, and, in the same way, between the independent variable $\mathrm{CE}$ and the dependent variable COO. This same analysis cannot support beta coefficients being significantly different from zero between the independent variables $\mathrm{CE}, \mathrm{SN}$, and $\mathrm{COO}$ and the dependent variable OPB. This result indicates that with an increase/decrease in the PBC, ATOP variables' values implies an increase/decrease in the OPB variable. These effects follow the theory of planned behavior. On the other hand, it is not supported that the variation of the $\mathrm{SN}$ values impacts OPB. One explanation is that subjective norms are perceived as the same for these consumers, and in a pandemic context, and there is not enough variation for the model to detect it. In the case of the relationship between $\mathrm{CE}$ and $\mathrm{COO}$, an increase/decrease in the values of the $\mathrm{CE}$ variable implies an increase/decrease in the COO variable, a situation following the idea of social identity in the context of consumer 
behavior. Finally, the COO variation does not affect the OPB variation. A possible reason is that most products bought online for the consumers surveyed in a pandemic context do not include the country of origin as an essential attribute. Consequently, hypotheses $\mathrm{H} 2$, $\mathrm{H} 4$, and $\mathrm{H} 5$ are supported for the model.

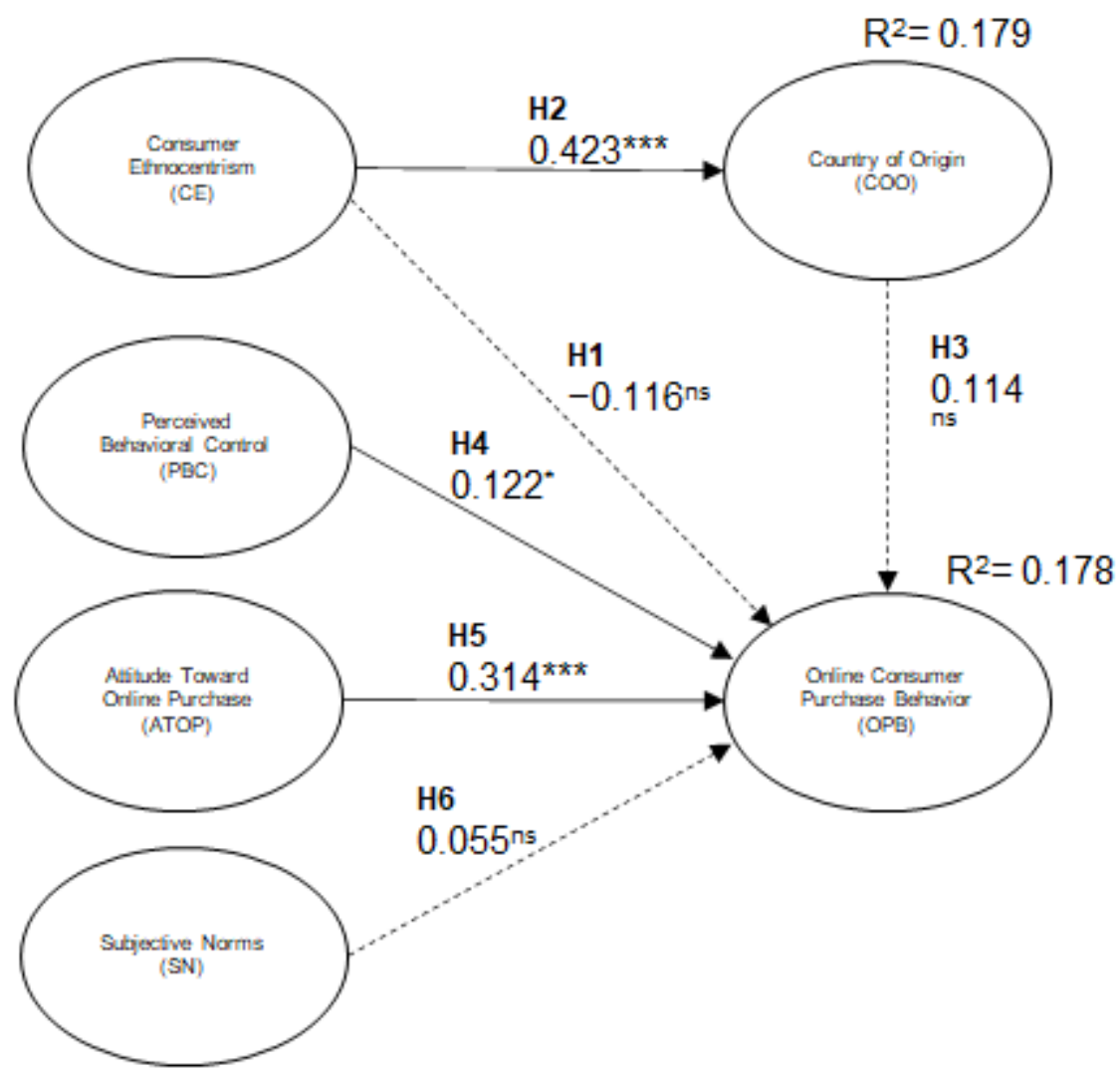

Figure 2. PLS results. Notes: ${ }^{* * *} p$-value $<0.001,{ }^{*} p$-value $<0.05$, ns non-significant.

\section{Discussion}

This study reviewed the effects of $\mathrm{CE}$ and $\mathrm{COO}$ on OPB in times of pandemics utilizing the TPB in a developing country. It is essential to point out that the study results align with the TPB and confirm the theory's strength within the e-commerce environment. Although $\mathrm{CE}, \mathrm{COO}$, and TPB have been studied before, this study addresses two critical issues in international business and marketing: evaluating the three in the e-commerce environment and their significance in times of health, economic, and social crisis.

\subsection{Theoretical Implications}

This study makes the following contributions to the literature. First, it finds that PBC has a mild effect on OPB when consumers are facing the impact of a pandemic. This result is in the same line as $[77,78]$, whose findings indicate that PBC influences OPB positively. This first finding shows that consumers' intentions toward Internet purchases are significantly affected by the consumers' perceived behavioral control. In other words, the ease in purchasing partially determined the online purchase. In marketing and international business, specifically in e-commerce, this information is relevant because consumers understand that they control the decision-making process in their purchases. Therefore, the entire virtual environment must be designed to stimulate and promote that perception. Nevertheless, a cross-country review shows that PBC is not always an antecedent to purchasing [80]. In the case of online consumers in Colombia, the results of our study indicate this effect, which is remarkable. In marketing and international business, specifically in e-commerce, this information is relevant because consumers understand that they control the decision-making process in their purchases. Therefore, the entire virtual environment must be designed to 
stimulate and promote that perception. In this vein, and from a broader view, a complete and cheaper access to the Internet in developing countries, in addition to other essential benefits, can promote online purchases.

Second, in alignment with other studies' previous results related to e-commerce and the TPB [76-79], this study finds that ATOP has a large effect on OPB. The favorability of consumers in times of pandemic for online purchases was demonstrated with this result. Undoubtedly, e-commerce plays a unique role when the population faces the waves of a crisis such as COVID-19. This preference and positive attitude toward online purchasing is essential for international business and marketing strategy decision-makers. These results are linked to [27] and [29] when they stated the perceptual relationship between sustainability and e-commerce customer engagement and, being more specific, how this practice could promote environmentally-friendly lifestyles.

Moreover, it is indispensable to adequate product and distribution platforms to satisfy this "in-crescendo" market reality. It is necessary to highlight that our findings related to SN are similar to those of [77] but in contradiction with the research outcomes of [78]. Hassan et al. [80] suggested that cultural differences affect the relationship between SN and consumer intention and that power distance is a necessary and sufficient cultural dimension to explain the cross-country variation found. In this way, the effect of SN on the purchase will be stronger in countries high in power distance than in countries low in power distance. Previous COVID-19 pandemic studies back this suggestion in countries high in power distance $[81,82]$. Our results do not support that the variation of the SN values impacts OPB. One explanation is that subjective norms are perceived as the same for Colombian consumers and in a pandemic context, and there is not enough variation for the model to detect it. This means that in times of a global pandemic, where physical contact has decreased to an unprecedented maximum, the perception of the Colombian consumer that everyone whom they consider important thinks that they should take care of themselves and not be exposed to the COVID-19 disease, preferring shopping online, is the same for everyone.

Third, this research suggests that $C E$ exhibits a negative and not significant effect on OPB. Our findings contradict the results stated by $[27,41,42]$, at least in times of a pandemic. These results are crucial when potential markets evaluate the quality and performance of international and local goods and select the best one. E-commerce offers an essential array of possibilities to consumers. Purchasing habits for domestic and foreign products might not be the main criteria to motivate the decision-making process. Accessibility, delivery process, truthfulness, and product assortment could be the fundamental variables consumers consider in times of a pandemic.

Fourth, the COO's results demonstrate that the relationship with OPB is not significant. These findings are in the same line as those of [61] and the results presented by [62] that indicated customers are interested in direct quality indicators.

\subsection{Managerial Implications}

This study has implications for both international brand managers and native brand managers regarding e-commerce.

Considering the study results, we want to highlight three specific aspects of the online buying behavior of Colombian consumers during the pandemic, and that may or may not vary after the pandemic. First, the ethnocentrism of the consumer appears as a non-determinant of online shopping in a pandemic scenario in Colombia. However, recent results in European consumers indicate the opposite [82]. An explanation could lie in the differentiated quality of local production between developed and developing countries. In this sense, in a post-pandemic scenario, Colombian online consumption behavior should not change concerning this determinant unless local production increases its quality. Second, social norms do not have an effect in explaining online shopping. Given that Colombia is a country high in the cultural dimension distance to power, it is expected that in ordinary times this effect can be detected in models based on the TPB [80]. 
Third, the global health crisis triggered the use of information technologies by people and organizations and the access to banking services to the population around the world. These two drivers have placed various countries, including Colombia, in a flourishing stage for electronic commerce. The Diffusion of Innovation Theory [83] suggests that this exponential advance should be followed by a period of moderate advancement in adopting online shopping in Colombia. We believe that in this future period, the effect of PBC will be moderated by variables such as age, gender, and experience on digital platforms [84].

Based on these results, marketers in developing countries should assimilate that the ATOP supports OPB in times of a pandemic, which means the clear preference consumers exhibit to buy products and services through business virtual platforms. International and local marketing managers should evaluate the strategies to keep consumers motivated toward their brands and products, considering that $\mathrm{CE}$ and $\mathrm{COO}$ are not fundamental variables of decision in times of a social crisis. Due to the economic crisis that COVID-19 has imposed, perceived high-quality benefits and the price could be essential variables consumers adopt to solve their needs.

On a more general note, our findings point to several ways that marketing and international managers could react to times of pandemics. Still, the lesson learned is to be prepared and design and build a solid structure to be ready. Beyond this, businesses should add specific benefits to their products and services that consumers can decode as unique, increasing the overall country perception. Additionally, in terms of selecting international markets to trade products and services, based on an in-depth analysis, the first should be those countries characterized as having low CE levels.

\subsection{Limitations and Future Research}

The present study has four limitations, which create opportunities for future studies. First, this study's research context is in Colombia. Future studies should examine consumers in other countries and regions. Second, limitations imposed by the Colombian Government related to social distancing and sanitary prohibitions did not reach a very significant sample population for this study. Research should apply and test the study's model with more representative samples. Third, future research can examine and compare different countries to evaluate the effects of $\mathrm{CE}, \mathrm{COO}$, and $\mathrm{OPB}$ considering diverse society, cultural, political, and economic facts. Last but not least, forthcoming studies should consider other theories and constructs to explore e-commerce to explain consumer perception, attitude, and behavior to deepen our understanding of the online/Internet shopping phenomenon in regular times and pandemics.

Author Contributions: Conceptualization, L.J.C. and P.E.R.-C.; methodology, L.J.C. and P.E.R.-C.; software, P.E.R.-C.; validation, P.E.R.-C.; formal analysis, P.E.R.-C.; investigation, L.J.C. and P.E.R.-C.; resources, L.J.C. and C.S.-C.; data curation, P.E.R.-C.; writing-original draft preparation, L.J.C. and C.S.-C.; writing-review and editing, L.J.C. and P.E.R.-C.; visualization, P.E.R.-C.; supervision, L.J.C. and P.E.R.-C.; project administration, L.J.C. and P.E.R.-C.; funding acquisition, L.J.C. and C.S.-C.. All authors have read and agreed to the published version of the manuscript.

Funding: This research received no external funding.

Institutional Review Board Statement: Not applicable.

Informed Consent Statement: Not applicable.

Data Availability Statement: The data presented in this study are available on request from the corresponding author.

Conflicts of Interest: The authors declare no conflict of interest. 


\section{Appendix A}

Table A1. Questionnaire.

\begin{tabular}{|c|c|}
\hline Latent Variable/Item & Scale \\
\hline \multicolumn{2}{|l|}{ Attitude Toward Online Purchase (ATOP) } \\
\hline $\begin{array}{l}\text { Buying things online is a. } \\
\text { Buying things online is a. } \\
\text { Buying things online is an idea that I. } \\
\text { Using the Internet to buy things would be. } \\
\text { Subjective Norms (SN) }\end{array}$ & $\begin{array}{l}\text { Very bad idea-Very good idea } \\
\text { Very silly idea-Very intelligent idea } \\
\text { Dislike a lot-I like too much } \\
\text { Very unpleasant-Very pleasant }\end{array}$ \\
\hline $\begin{array}{l}\text { People who influence my behavior would think I should buy things online. } \\
\text { People who are important to me would think I should buy things online. } \\
\text { Perceived behavioral control (PBC) }\end{array}$ & $\begin{array}{l}\text { Strongly disagree-Strongly agree } \\
\text { Strongly disagree-Strongly agree }\end{array}$ \\
\hline $\begin{array}{l}\text { I'm able to buy things online. } \\
\text { Buying things online is completely under my control. } \\
\text { I have the resources, the knowledge and the ability to buy things online. } \\
\text { Online shopping behavior (OPB) }\end{array}$ & $\begin{array}{l}\text { Strongly disagree-Strongly agree } \\
\text { Strongly disagree-Strongly agree } \\
\text { Strongly disagree-Strongly agree }\end{array}$ \\
\hline $\begin{array}{l}\text { How much would I say you spend on online shopping each month? } \\
\text { Consumer Ethnocentrism (CE) }\end{array}$ & Nothing to 250 dollars \\
\hline $\begin{array}{l}\text { We should always buy local products instead of imports. } \\
\text { Only products that are not available in our country should be imported. } \\
\text { Buying our domestic products keeps our people working. } \\
\text { Local products, from the first to the last, are always the most important. } \\
\text { Buying foreign products is anti-Colombian. } \\
\text { It is not right to buy foreign products. } \\
\text { An authentic Colombian should buy products made in Colombia. } \\
\text { We should buy products manufactured in Colombia instead of making other countries } \\
\text { rich at our expense. } \\
\text { It is always better to buy Colombian products. } \\
\text { There should be little marketing of products from other countries unless it is a necessity. } \\
\text { Colombians should not buy foreign products because they damage Colombian businesses } \\
\text { and cause unemployment. } \\
\text { Restrictions should be placed on all imports. } \\
\text { It could cost me more in the long run, but I prefer to support Colombian products. } \\
\text { Foreigners should not be allowed to place their products in our markets. } \\
\text { Foreign products should be taxed highly to reduce their entry into Colombia. } \\
\text { We should buy foreign products only if these products cannot be obtained within } \\
\text { our country. } \\
\text { Colombian consumers who buy imported products are responsible for putting their } \\
\text { compatriots out of work. } \\
\text { Country of Origin (COO) }\end{array}$ & $\begin{array}{l}\text { Strongly disagree-Strongly agree } \\
\text { Strongly disagree-Strongly agree } \\
\text { Strongly disagree-Strongly agree } \\
\text { Strongly disagree-Strongly agree } \\
\text { Strongly disagree-Strongly agree } \\
\text { Strongly disagree-Strongly agree } \\
\text { Strongly disagree-Strongly agree } \\
\text { Strongly disagree-Strongly agree } \\
\text { Strongly disagree-Strongly agree } \\
\text { Strongly disagree-Strongly agree } \\
\text { Strongly disagree-Strongly agree } \\
\text { Strongly disagree-Strongly agree } \\
\text { Strongly disagree-Strongly agree } \\
\text { Strongly disagree-Strongly agree } \\
\text { Strongly disagree-Strongly agree } \\
\text { Strongly disagree-Strongly agree } \\
\text { Strongly disagree-Strongly agree }\end{array}$ \\
\hline $\begin{array}{l}\text { When buying imported products, the country of origin is the information I take into } \\
\text { consideration. }\end{array}$ & Strongly disagree-Strongly agree \\
\hline $\begin{array}{l}\text { I look for the information of the country of origin to select the best imported product } \\
\text { available in the market. }\end{array}$ & Strongly disagree-Strongly agree \\
\hline I understand that the country of origin determines the quality of the imported products. & Strongly disagree-Strongly agree \\
\hline $\begin{array}{l}\text { When I buy expensive imported products, I always look for which country it was } \\
\text { manufactured in. }\end{array}$ & Strongly disagree-Strongly agree \\
\hline $\begin{array}{l}\text { If I have little experience in the type of imported product, I look for the information of the } \\
\text { country of origin to help me make a better decision. }\end{array}$ & Strongly disagree-Strongly agree \\
\hline
\end{tabular}




\section{References}

1. Schmid, S.; Kotulla, T. 50 years of research on international standardization and adaptation-From a systematic literature analysis to a theoretical framework. Int. Bus. Rev. 2011, 20, 491-507. [CrossRef]

2. Mandler, T.; Sezen, B.; Chen, J.; Özsomer, A. Performance consequences of marketing standardization/adaptation: A systematic literature review and future research agenda. J. Bus. Res. 2021, 125, 416-435. [CrossRef]

3. Carpenter, J.; Moore, M.; Doherty, A.M.; Alexander, N. Acculturation to the global consumer culture: A generational cohort comparison. J. Strat. Mark. 2012, 20, 411-423. [CrossRef]

4. Woodside, A.G.; Hsu, S.-Y.; Marshall, R. General theory of cultures' consequences on international tourism behavior. J. Bus. Res. 2011, 64, 785-799. [CrossRef]

5. Pharr, J.M. Synthesizing Country-of-Origin Research from the Last Decade: Is the Concept Still Salient in an Era of Global Brands? J. Mark. Theory Pract. 2005, 13, 34-45. [CrossRef]

6. Tate, W.L.; Ellram, L.M.; Schoenherr, T.; Petersen, K.J. Global competitive conditions driving the manufacturing location decision. Bus. Horiz. 2014, 57, 381-390. [CrossRef]

7. Leonard, L.N.K.; Jones, K. Consumer-to-Consumer Ecommerce: Acceptance and Intended Behavior. Commun. IIMA 2014, 14, 1-20.

8. Maciaszczyk, M.; Kocot, M. Behavior of Online Prosumers in Organic Product Market as Determinant of Sustainable Consumption. Sustainability 2021, 13, 1157. [CrossRef]

9. Liu, Y.; Qu, Y.; Lei, Z.; Jia, H. Understanding the Evolution of Sustainable Consumption Research. Sustain. Dev. 2017, 25, 414-430. [CrossRef]

10. Griffin, R.W. Fundamentals of Management; Cengage: Boston, MA, USA, 2013.

11. Review of the EU Sustainable Development Strategy-Renewed Strategy. Available online: https://www.etuc.org/en/revieweusustainable-development-strategy (accessed on 10 December 2021).

12. Sustainable Consumption Helping Consumers Make Eco-Friendly Choices. Available online: https://www.europarl.europa.eu/ RegData/etudes/BRIE/2020/659295/EPRS_BRI(2020)659295_EN.pdf (accessed on 10 December 2021).

13. Abedniya, A.; Zaeim, M.N. The impact of country of origin and ethnocentrism as major dimensions in consumer purchasing behavior in fashion industry. Eur. J. Econ. Financ. Adm. Sci. 2011, 33, 222-232.

14. Camacho, L.J.; Salazar-Concha, C.; Ramírez-Correa, P. The Influence of Xenocentrism on Purchase Intentions of the Consumer: The Mediating Role of Product Attitudes. Sustainability 2020, 12, 1647. [CrossRef]

15. Swaminathan, V.; Page, K.L.; Gürhan-Canli, Z. "My" brand or "our" brand: The effects of brand relationship dimensions and self-construal on brand evaluations. J. Consum. Res. 2007, 34, 248-259. [CrossRef]

16. Wanninayake, W.M.C.B.; Chovancova, M. Consumer Ethnocentrism and Attitudes towards Foreign Beer Brands: With Evidence from Zlin Region in the Czech Republic. J. Compet. 2012, 4, 3-19. [CrossRef]

17. Oláh, J.; Kitukutha, N.; Haddad, H.; Pakurár, M.; Máté, D.; Popp, J. Achieving Sustainable E-Commerce in Environmental, Social and Economic Dimensions by Taking Possible Trade-Offs. Sustainability 2019, 11, 89. [CrossRef]

18. Pei, X.-L.; Guo, J.-N.; Wu, T.-J.; Zhou, W.-X.; Yeh, S.-P. Does the Effect of Customer Experience on Customer Satisfaction Create a Sustainable Competitive Advantage? A Comparative Study of Different Shopping Situations. Sustainability 2020, 12, 7436. [CrossRef]

19. Saha, S.K.; Duarte, P.; Silva, S.C.; Zhuang, G. Supporting sustainability by promoting online purchase through enhancement of online convenience. Environ. Dev. Sustain. 2021, 23, 7251-7272. [CrossRef]

20. He, J.; Wang, C.L. Cultural identity and consumer ethnocentrism impacts on preference and purchase of domestic versus import brands: An empirical study in China. J. Bus. Res. 2015, 68, 1225-1233. [CrossRef]

21. Akdogan, M.S.; Ozgener, S.; Kaplan, M.; Coskun, A. The effects of consumer ethnocentrism and consumer animosity on the re-purchase intent: The moderating role of consumer loyalty. EMAJ: Emerg. Mark. J. 2012, 2, 1-12. [CrossRef]

22. Pentz, C.; Terblanche, N.S.; Boshoff, C. Measuring Consumer Ethnocentrism in a Developing Context: An Assessment of the Reliability, Validity and Dimensionality of the CETSCALE. J. Transnatl. Manag. 2013, 18, 204-218. [CrossRef]

23. Godey, B.; Pederzoli, D.; Aiello, G.; Donvito, R.; Chan, P.; Oh, H.; Singh, R.; Skorobogatykh, I.; Tsuchiya, J.; Weitz, B. Brand and country-of-origin effect on consumers' decision to purchase luxury products. J. Bus. Res. 2012, 65, 1461-1470. [CrossRef]

24. Montanari, M.G.; Rodrigues, J.M.; Giraldi, J.D.M.E.; Neves, M.F. Country of origin effect: A study with Brazilian consumers in the luxury market. Braz. Bus. Rev. 2018, 15, 348-362. [CrossRef]

25. Akter, S.; Wamba, S.F.; Dewan, S. Why PLS-SEM is suitable for complex modelling? An empirical illustration in big data analytics quality. Prod. Plan. Control. 2017, 28, 1011-1021. [CrossRef]

26. Henseler, J.; Ringle, C.M.; Sinkovics, R.R. The use of partial least squares path modeling in international marketing. In Advances in International Marketing; Sinkovics, R.R., Ghauri, P.N., Eds.; Emerald Group Publishing Limited: Bradford, UK, 2009; pp. 277-319. [CrossRef]

27. Shimp, T.A.; Sharma, S. Consumer Ethnocentrism: Construction and Validation of the CETSCALE. J. Mark. Res. 1987, 24, 280-289. [CrossRef]

28. Sharma, P. Consumer ethnocentrism: Reconceptualization and cross-cultural validation. J. Int. Bus. Stud. 2015, 46, 381-389. [CrossRef]

29. Keillor, B.D.; Parker, R.S.; Schaefer, A. Influences on adolescent brand preferences in the United States and Mexico. J. Advert. Res. 1996, 36, 47-57. 
30. Alden, D.L.; Kelley, J.B.; Riefler, P.; Lee, J.A.; Soutar, G.N. The Effect of Global Company Animosity on Global Brand Attitudes in Emerging and Developed Markets: Does Perceived Value Matter? J. Int. Mark. 2013, 21, 17-38. [CrossRef]

31. Surdu, I.; Mellahi, K.; Glaister, K.W. Once bitten, not necessarily shy? Determinants of foreign market re-entry commitment strategies. J. Int. Bus. Stud. 2018, 50, 393-422. [CrossRef]

32. Magnusson, P.; Krishnan, V.; Westjohn, S.A.; Zdravkovic, S. The Spillover Effects of Prototype Brand Transgressions on Country Image and Related Brands. J. Int. Mark. 2014, 22, 21-38. [CrossRef]

33. Balabanis, G.; Siamagka, N.T. Inconsistencies in the behavioural effects of consumer ethnocentrism: The role of brand, product category and country of origin. Int. Mark. Rev. 2017, 34, 166-182. [CrossRef]

34. Tajfel, H.; Turner, J.C. The Social Identity Theory of Intergroup Behavior. In Political Psychology: Key Readings; Jost, J., Sidanius, J., Eds.; Psychology Press: East Sussex, UK, 2004; pp. 276-293.

35. Cleveland, M.; Balakrishnan, A. Appreciating vs venerating cultural outgroups: The psychology of cosmopolitanism and xenocentrism. Int. Mark. Rev. 2019, 36, 416-444. [CrossRef]

36. Hsu, J.L.; Nien, H.-P. Who are ethnocentric? Examining consumer ethnocentrism in Chinese societies. J. Consum. Behav. 2008, 7, 436-447. [CrossRef]

37. Balabanis, G.; Diamantopoulos, A.; Mueller, R.D.; Melewar, T.C. The Impact of Nationalism, Patriotism and Internationalism on Consumer Ethnocentric Tendencies. J. Int. Bus. Stud. 2001, 32, 157-175. [CrossRef]

38. Wade, P. The Meaning of 'Race' and 'Ethnicity'. In Race and Ethnicity in Latin America; Pluto Press: London, UK, 2010; pp. 4-23. [CrossRef]

39. Sumner, W.G. Folkways, a Study of the Sociological Importance of Usages, Manners, Customs, Mores and Morals. Am. J. Psychol. 1907, 18, 376. [CrossRef]

40. Schooler, R.D. Product Bias in the Central American Common Market. J. Mark. Res. 1965, 2, 394-397. [CrossRef]

41. Smyczek, S.; Glowik, M. Ethnocentrism of Polish consumers as a result of the global economic crisis. J. Cust. Behav. 2011, 10, 99-118. [CrossRef]

42. Klein, J.G.; Ettenson, R.; Morris, M.D. The animosity model of foreign product purchase: An empirical test in the People's Republic of China. J. Mark. 1998, 62, 89-100. [CrossRef]

43. Kim, S.; Pysarchik, D.T. Predicting purchase intentions for uni-national and bi-national products. Int. J. Retail. Distrib. Manag. 2000, 28, 280-291. [CrossRef]

44. Moon, S.-J.; Nelson, M.R. Exploring the influence of media exposure and cultural values on Korean immigrants' advertising evaluations. Int. J. Advert. 2008, 27, 299-330. [CrossRef]

45. Maksan, M.T.; Kovačić, D.; Cerjak, M. The influence of consumer ethnocentrism on purchase of domestic wine: Application of the extended theory of planned behaviour. Appetite 2019, 142, 104393. [CrossRef] [PubMed]

46. Hien, N.N.; Phuong, N.N.; Van Tran, T.; Thang, L.D. The effect of country-of-origin image on purchase intention: The mediating role of brand image and brand evaluation. Manag. Sci. Lett. 2020, 10, 1205-1212. [CrossRef]

47. Rezvani, S.; Dehkordi, G.J.; Rahman, M.S.; Fouladivanda, F.; Habibi, M.; Eghtebasi, S. A Conceptual Study on the Country of Origin Effect on Consumer Purchase Intention. Asian Soc. Sci. 2012, 8, 205. [CrossRef]

48. Johansson, J.K.; Douglas, S.P.; Nonaka, I. Assessing the Impact of Country of Origin on Product Evaluations: A New Methodological Perspective. J. Mark. Res. 1985, 22, 388-396.

49. Insch, G.S.; McBride, J.B. The impact of country-of-origin cues on consumer perceptions of product quality: A binational test of the decomposed country-of-origin construct. J. Bus. Res. 2004, 57, 256-265. [CrossRef]

50. Han, C.M.; Terpstra, V. Country-of-Origin Effects for Uni-National and Bi-National Products. J. Int. Bus. Stud. 1988, 19, 235-255. [CrossRef]

51. Wang, C.K.; Lamb, C.W. The impact of selected environmental forces upon consumers' willingness to buy foreign products. J. Acad. Mark. Sci. 1983, 11, 71-84. [CrossRef]

52. Usunier, J.-C.; Cestre, G. Product Ethnicity: Revisiting the Match between Products and Countries. J. Int. Mark. 2007, 15, 32-72. [CrossRef]

53. Verlegh, P.W.J.; Steenkamp, J.B.E.M.; Meulenberg, M.T.G. Country-of-origin effects in consumer processing of advertising claims. Int. J. Res. Mark. 2005, 22, 127-139. [CrossRef]

54. Knight, J.G.; Holdsworth, D.K.; Mather, D. Country-of-origin and choice of food imports: An in-depth study of European distribution channel gatekeepers. J. Int. Bus. Stud. 2007, 38, 107-125. [CrossRef]

55. Insch, A.; Williams, S.; Knight, J.G. Managerial Perceptions of Country-of-Origin: An Empirical Study of New Zealand Food Manufacturers. J. Food Prod. Mark. 2015, 22, 304-319. [CrossRef]

56. Dekhili, S.; D'Hauteville, F. Effect of the region of origin on the perceived quality of olive oil: An experimental approach using a control group. Food Qual. Prefer. 2009, 20, 525-532. [CrossRef]

57. Loureiro, M.L.; Umberger, W.J. A choice experiment model for beef: What US consumer responses tell us about relative preferences for food safety, country-of-origin labeling and traceability. Food Policy 2007, 32, 496-514. [CrossRef]

58. Chung, C.; Boyer, T.; Han, S. Valuing Quality Attributes and Country of Origin in the Korean Beef Market. J. Agric. Econ. 2009, 60, 682-698. [CrossRef]

59. Vukasovič, T. European meat market trends and consumer preference for poultry meat in buying decision making process. World's Poult. Sci. J. 2014, 70, 289-302. [CrossRef] 
60. Kemp, K.; Insch, A.; Holdsworth, D.K.; Knight, J.G. Food miles: Do UK consumers actually care? Food Policy 2010, 35, 504-513. [CrossRef]

61. Verbeke, W.; Ward, R.W. Consumer interest in information cues denoting quality, traceability and origin: An application of ordered probit models to beef labels. Food Qual. Prefer. 2006, 17, 453-467. [CrossRef]

62. Yong, C.K.; Eskridge, K.M.; Calkins, C.R.; Umberger, W.J. Assessing consumer preferences for rib-eye steak characteristics using confounded factorial conjoint choice experiments. J. Muscle Foods 2010, 21, 224-242. [CrossRef]

63. Unahanandh, S.; Assarut, N. Dairy Products Market Segmentation: The Effects of Country of Origin on Price Premium and Purchase Intention. J. Int. Food Agribus. Mark. 2013, 25, 122-133. [CrossRef]

64. Dursun, I.; Kabadayi, E.T.; Ceylan, K.E.; Köksal, C.G. Russian Consumers Responses to Turkish Products: Exploring the Roles of Country Image, Consumer Ethnocentrism, and Animosity. Bus. Econ. Res. J. 2019, 10, 499-515. [CrossRef]

65. Gómez-Díaz, L. Destination Image in the COVID-19 Crisis: How to Mitigate the Effect of Negative Emotions, Developing Tourism Strategies for Ethnocentric and Cosmopolitan Consumers. Multidiscip. Bus. Rev. 2021, 14, 1-10. [CrossRef]

66. Lee, H.-J. The Impact of Consumer Competence in Purchasing Foods on Satisfaction with Food-Related Consumer Policies and Satisfaction with Food-Related Life through Perceptions of Food Safety. Foods 2020, 9, 1103. [CrossRef] [PubMed]

67. Ha-Brookshire, J.; Yoon, S.-H. Country of origin factors influencing US consumers' perceived price for multinational products. J. Consum. Mark. 2012, 29, 445-454. [CrossRef]

68. Augusta, E.D.; Mardhiyah, D.; Widiastuti, T. Effect of country of origin image, product knowledge, brand familiarity to purchase intention Korean cosmetics with information seeking as a mediator variable: Indonesian women's perspective. Dermatol. Rep. 2019, 11, 7-10. [CrossRef]

69. Nguyen, P.V.; Tran, K.T.; Le, H.M.P.T. Effects of country of origin, foreign product knowledge and product features on customer purchase intention of imported powder milk. Int. J. Bus. Innov. Res. 2019, 19, 139-161. [CrossRef]

70. Ajzen, I. From intentions to actions: A theory of planned behavior. In Action Control: From Cognition to Behavior; Kuhl, J., Beckman, J., Eds.; Springer: Berlin/Heidelberg, Germany; New York, NY, USA, 1985; pp. 11-39.

71. Ajzen, I. The theory of planned behaviour: Reactions and reflections. Psychol. Health 2011, 26, 1113-1127. [CrossRef]

72. Bandura, A. On the Functional Properties of Perceived Self-Efficacy Revisited. J. Manag. 2011, 38, 9-44. [CrossRef]

73. Bandura, A. Self-efficacy mechanism in human agency. Am. Psychol. 1982, 37, 122-147. [CrossRef]

74. Chiang, K.-P.; Jackson, A. Consumer vulnerability in the context of direct-to-consumer prescription drug. Int. J. Healthc. Manag. 2012, 5, 108-113. [CrossRef]

75. Gu, S.; Wu, Y. Using the Theory of Planned Behaviour to explain customers' online purchase intention. World Sci. Res. J. 2019, 5, 226-249.

76. George, J. The theory of planned behavior and Internet purchasing. Internet Res. 2004, 14, 198-212. [CrossRef]

77. Dezdar, S. Green information technology adoption: Influencing factors and extension of theory of planned behavior. Soc. Responsib. J. 2017, 13, 292-306. [CrossRef]

78. Gangwal, N.; Bansal, V. Application of Decomposed Theory of Planned Behavior for M-commerce Adoption in India. In Proceedings of the 18th International Conference on Enterprise Information Systems, ICEIS 2016, Rome, Italy, 25-28 April 2016; pp. 357-367.

79. Hassan, L.M.; Shiu, E.; Parry, S. Addressing the cross-country applicability of the theory of planned behaviour (TPB): A structured review of multi-country TPB studies. J. Consum. Behav. 2015, 15, 72-86. [CrossRef]

80. Redda, E.H. Attitudes towards online shopping: Application of the theory of planned behaviour. Acta Univ. Danubius. Acon. 2019, 2, 148-159.

81. Yaghoubi, N.-M.; Bahmani, E. Factors affecting the adoption of online banking: An integration of technology acceptance model and theory of planned behavior. Int. J. Bus. Manag. 2010, 9, 159-165.

82. Migliore, G.; Rizzo, G.; Schifani, G.; Quatrosi, G.; Vetri, L.; Testa, R. Ethnocentrism Effects on Consumers' Behavior during COVID-19 Pandemic. Economies 2021, 9, 160. [CrossRef]

83. Rogers, E.M. Diffusion of Innovations; Simon and Schuster: New York, NY, USA, 2010.

84. Venkatesh, V.; Thong, J.Y.L.; Xu, X. Consumer acceptance and use of information technology: Extending the unified theory of acceptance and use of technology. MIS Q. 2012, 36, 157-178. [CrossRef] 